\title{
Phyto-diversity Study with Special Reference to Herbaceous Medicinal Plants
}

\section{Patel DK}

Department of Rural Technology, Guru Ghasidas Vishwavidyalaya, Bilaspur, 495009, Chhattisgarh, India

*Corresponding author: Patel DK, Department of Rural Technology, Guru Ghasidas Vishwavidyalaya, Bilaspur, 495009, Chhattisgarh, India, Tel: 09993660173; E-mail: dplantscience@yahoo.co.in

Rec date: Feb 27, 2014; Acc date: Mar 24, 2014; Pub date: Mar 30, 2014

Copyright: (C) 2014 Patel DK, This is an open-access article distributed under the terms of the Creative Commons Attribution License, which permits unrestricted use, distribution, and reproduction in any medium, provided the original author and source are credited.

\begin{abstract}
Chhattisgarh is rich center of Biodiversity also known as an Herbal state in India. Among the diversity of species, Medicinal plants diversity is of great importance. The state is covered with $44.00 \%$ area by forest cover. Traditional medicinal plants are used by local people to cure many diseases over the state.

The plant resources are a remarkable natural source for providing many useful products. Medicinal plants diversity with special references to herbaceous plants was assessed and documented in this study. Information on Medicinal plants was recorded by surveying the area during July 2010 to June 2011.

Based on the field survey there are 116 Medicinal plants belonging to 43 families were documented in and around area of Bilaspur (C. G.). Leaf is recorded as maximum used plant parts, Seed is shown as a main source to multiply the plants and the data are discussed furthermore.
\end{abstract}

Keywords: Plant diversity; Medicinal plants; Field survey

\section{Introduction}

Bilaspur is the major District of Chhattisgarh state located in SouthWest part of the state enriched with plant diversity. The study area is located between $21^{\circ} 47^{\prime}$ and $23^{\circ} 8^{\prime}$ north latitudes and $81^{\circ} 14^{\prime}$ and $83^{\circ} 15^{\prime}$ east latitudes and average elevation of 264 meters $(866 \mathrm{ft})$. The climate of the area is humid and monsoon type. In summer season temperature is in the range of $30-47^{\circ} \mathrm{C}$ and in winter between $5-25^{\circ} \mathrm{C}$. The areas having black-sandy soil is rich in water holding capacity.

Above environmental condition support the diversity of different plant species. Many of the recorded plants are of Medicinal plants used by the local people as a source of their primary health care. A large number of studies have been made on Medicinal plants and their use in India found in Ambasta et al.[1], Chandra et al. [2] etc. Around 80\% of the Herbal medicines derived from Medicinal plants are the main source for primary health care over the World.

People of rural areas have more practices on the use and conservation of the plants for various economic values. They utilize both cultivated and wild plant species in their life and as per their knowledge and need, and playing a role in conservation of the plants.

A large number of plant species have great significance for the people. Among them Medicinal plants are majorly utilized by the people to treat many diseases not only in India and also all over the world. India is marked as home of around $15 \%$ Medicinal plants over the World. Approximately $90 \%$ of the plant population is growing in varied climatic zones of the India [3].

The current study focuses on documentation of diversity of plants especially herbaceous Medicinal Plants in Bilaspur (C.G.). About 95\% of the Wild plants are major source for raw materials of pharmaceuticals to develop drugs [4]. India is a rich center of plant diversity having around 45000 species spread over the country [5].
India is also known as a mega-diversity center among 12 in the world [6]. There are 16 Agro-climatic zones, 10 Vegetative zones also. Gradually the demand of herbal medicines is increasing due to its ecofriendly, low cast, easily availability and effectiveness to cure many diseases

Destruction of the natural habitat, Over-exploitation, Nontechnical collection, Developmental activities etc. are responsible for loss of the Medicinal plants in any specified area. A sharp decreasing trend of the biological species is coming on light day by day. So, it is necessary for assessment of plant diversity, so that it can be made effort to conserve the needful bio-species. Due to use of synthetic drugs many diseases are increasing in such condition utility of herbal medicine is increasing.

Plant Biodiversity study in Hazaribag District. (JH) in India was studied by Lal and Singh [7]. Ethno medicinal plants study of Sheopur district. (M.P.) for District. Rewa and Kumau Himalayan region was noticed by Pathak and Mishra, Shukla, Gangwarand Gangwar et al. [8-10] individually. Study on floristic diversity and conservation status in sacred groves in Kanyakumari District (T.N.) was done by Sukumaran et al. [11].

Scientifically documentation and researches on Medicinal plants are increasing in India due to their remarkable role in human life in the world. Now a day focuses on plant diversity assessment, Use and conservation is needful aspects towards scientific awareness and for maintaining existence of plants life on the earth. Many important drugs are derived from Medicinal plants are a major source for treatment of many diseases among the peoples.

The aim of the present research was to explore and assesses the Plant diversity especially herbaceous Medicinal plants in Bilaspur, Chhattisgarh, India. 


\section{Materials and Methods}

The study area was periodically surveyed and observations on plant diversity were made over the year in (2010-11). Collections of various plant species were made from different parts of the study area.

Collected Plants were documented following their Botanical name, Family, Habit, Useful parts and their propagation methods with the help of the literatures such as flora/ Encyclopedia like De LC, Hooker's, Sharma R, Tivedi PC, and Pullaiah T et al.[12-16].

\section{Results and Discussion}

The study was done to know the eco-taxonomical position of the Medicinal plants with special references to the herbaceous Medicinal plants. Findings of the present study is shown in Tables 1-4 (See Appendix-1) are Range wise distribution of the families, Useful plant parts of the Medicinal plants and Propagation methods of the Medicinal plants respectively (See Appendix-1).

There are 116species of Medicinal plants belonging to 43 families were observed and scientifically documented. The recorded plants are of valuable for many diseases as found by Sharma et al. [17,18].

Out of recorded herbaceous medicinal plants there are 37species registered their presence under the number range of 0-05 where as members of the family Asteraceae, Fabaceae, Lamiaceae, Liliaceae, Solanaceae, Zingiberaceae showed their species composition in the range 06-10 in number.

Maximum number of the plants belonging to the family Fabaceae, maximum 24 plants leaf part is used for various medicinal purposes as a source of herbal medicine. In second position (13) Whole plant part is taken in use as medicine. Rest of the plant species are utilized randomly order among the recorded species of Medicinal plants.

As the plants are showing variations in their presence and also in their properties due to presence of a variety of chemical compounds. Chemicals present inside of the plant body are variable between the plants and is also affected by their age and climatic conditions.

One disorder can be treated by a group of the plants and one plant is also capable to treat many disorders as example the plant Andrographis paniculata Nees is known as a king of bitter due to presence of Andrographin. This plant is used for treatment of various disorders like in Diabetes control, Malaria fever, Blood purification, worm killing etc. Important plant species useful in many disorders are grouped in Table 4 (See Appendix-1).

Due to easily availability, low cost and less side effect the use of the medicinal plants is increasing day by day.

Medicinal plants showed variable tendency in their propagation. Maximum percentage of Seed (65\%) is observed as a source of plant propagation. In second position Rhizomes (14) are used than Stem cutting [9), Seed/Stem cutting (4), Bulb, Tuber (3), Bud, Corm, Leaf (2) are recorded. Only one Medicinal plant Asparagus racemosus Wild is propagated by their Seed and Tuber also.

\section{References}

1. Ambasta SP (1986) The useful plants of India, Publication and Information: CSIR New Delhi, India.

2. Chandra A (2003) Traditional knowledge of ethno-medicine in Jaunsarbawar, Dehradun District. Indian Journal of Traditional Knowledge 2: 397-399.

3. Singh HB (1997) Alternate source for some conventional drug plants of India. In : Maheshwari, J. K. (Ed.), Ethnobotany and Medicinal plants of Indian Subcontinent, Scientific Publishers 109-114, Jodhpur, India.

4. Kehimkar I (2000) Common Indian Wild flowers, Bombay Natural Historical Society, Oxford University Press.

5. Maheswari J (2011) Patenting Indian Medicinal Plants and products, Indian Journal of Science and Technology 4: 298-301.

6. Kotwal D, Kumar S and Sahi DN (2009) Wintering birds in and around the vicinity of Lake Mansar, district Udhampur (J \& K). Current World Environment 4: 375-379.

7. Lal HS and Singh S (2012) Study of Plant Biodiversity of Hazaribag District (J. H.) India and its Medicinal uses. Bioscience Discovery 3: 91-96.

8. Pathak S and Mishra JK (2011) Some Ethno-medicinal Plants of Sheopur District, M.P. Indian J Sci Res 2: 133-134.

9. Shukla AN, Shriwastava S and Rawat AK (2010) An Ethno-botanical Study of Medicinal Plants of Rewa district, Madhya Pradesh. Indian Journal of Traditional Knowledge 9: 191-202.

10. Gangwar and Gangwar (2010) Ethno Medicinal Plant diversity in Kumaun Himalaya of Uttarakhand, India. Nature and Science 8: 66-78.

11. Sukumaran S, Jeeva S, Raj ADS, Kannan D (2008) Floristic diversity, Conservation status and Economic value of miniature sacred groves in Kanyakumari Distt., (T. N.) Southern Peninsular India. Turk J Bot 32: 185-199.

12. Bhattacharjee SK, L C De (2005) Medicinal herbs and flowers, Avishkar publishers, Jaipur, India.

13. Hooker JD (1875) Flora of British India, London: L. Reeve and Co, Canada.

14. Sharma R (2003) Medicinal plants of India-An Encyclopedia, Daya publishing House, Delhi, India.

15. Trivedi PC (2006) Medicinal plants: Ehno-botanical Approach, Agrobios publication, Agrobios, Jodhpur, India.

16. Pullaiah T (2006) Encyclopedia of World Medicinal plants. Regency Publication, New Delhi, India.

17. Nayak PK, Choudhary BP and Das J (2000) A Peep in to the Potential Medicinal Plants of Kalahandi District (Orissa). An Assessment. Bulletin of Pure and Applied Sciences, 19: 9-15.

18. Sharma NK (1990) Ethnomedicine of Mukundaras (S.E. Rajasthan) Plant remedies used in Guiena worm (Naaru) disease. Bull Bot Surv India. 32: 116-120. 